\title{
Anti-nutritional Composition of Honey Samples from Four Northern States of Nigeria
}

\author{
*O.B. Oriolowo, O.J. John, D.S. Abubakar, T.M. Jonah and D. Ismaila \\ Department of Biology, Federal College of Education P.M.B, Kontagora, Niger State, Nigeria \\ [Corresponding Author: E-mail: oriolowotayo@yahoo.ca; D:+2348032483295]
}

\section{ABSTRACT}

Honey is sought globally for nutritional and therapeutic purposes because of the several chemical constituents that are abound in it. Some of these chemicals such as the anti-nutrients are defensive metabolic byproducts of plants from which bees obtained the nectars for honey production. This study was undertaken to determine the cyanide, oxalate, phytate, tannin and saponin compositions of honey samples from four North Central States of Nigeria. Anti-nutrients were analyzed following the Standards of Association of Official Analytical Chemists protocol for anti-nutrient compositions. Data obtained were compared using One-Way Analysis of Variance (ANOVA) and the means were separated using Fischer's Least Significance Difference (LSD). The results showed that cyanide, phytate and tannin were present in all the four honey samples while oxalate and saponin were only present in two of the honey samples, though at varying concentrations each of them. All anti-nutrient except cyanide are within tolerable limit for human consumption. There were significant differences $(p<0.05)$ in each of the anti-nutrient's concentrations across the honey samples. The study showed that location and geographical region significantly influence honey's anti-nutrient compositions as well as their concentrations.

Keywords: Honey, Anti-nutrients, Tannin, Saponin, Cyanide, Oxalate, Phytate.

\section{INTRODUCTION}

Honey is the natural sweet substance produced by honey bee (Apis spp) from the nectar of plants or from secretion of living parts of plants or excretions of plant sucking insects on living parts of plants, which bees collect, transform, deposit, dehydrate, store and leave in honey comb to ripen and mature (CAC, 2001). It is a supersaturated sugar solution and the unique combination of its components makes it a priced addition to diet (David, 2007). Apart from its worldwide nutritional acceptability, honey had been found useful in management of wound, which enables healing and prevents the spread of infection to other body tissues (Oyeleke et al., 2010). Apart from its nutritional compositions it has other several phytochemicals (Kaskoniene and Venskutonis 2010). Honey is widely sought after not only because of its nutrients but sometimes because of it medicinal and health properties due to its phytochemicals (Buba et al., 2013).

Phytochemicals in honeys are influenced by the nectar composition and geographical location of foraged plants (Špánik et al., 2014). This is because nectars are derived from plant phloem sap and their exact composition varies tremendously based on plant species as well as environmental factors like pollution and soil nutrients (Špánik et al., 2014). A number of plant secondary metabolites are known to act as means of defense against herbivorous insects, pathogens as well as adverse growing conditions. These are secreted in the plant saps and accumulate in pollen and nectar at a level, which could significantly alter the chemical properties, or compromise the safety of honey produced from such plant's nectars (Brian, 2015). A group of such plant metabolites known as antinutrients is often neglected when setting safety standards for honey meant for consumption. Antinutrients or anti-nutritional factors are substances synthesized in plant by normal metabolisms or by other mechanisms (Akande et al., 2010). They are capable of precipitating deleterious effects in man and animals by reducing nutrients availability and utilization (Shanthakumari et al., 2008). They largely determine nutrients 


\section{Nigerian Journal of Basic and Applied Science (December, 2019), 27(2): 32-38}

bioavailability in humans as they interfere with the process of digestion, absorption and assimilation of intake food nutrients (Okaka and Okaka, 2005; Gilani et al., 2012).

Despite the fact that honey is widely consumed because of its accepted nutritional value (Buba et al., 2013), there is dearth of sufficient information on the anti-nutritional factors in them. This study was therefore undertaken to evaluate the antinutrient compositions of honey samples from Nasko, Warra, Lafiagi and Dongu Daji in Niger, Kebbi, Kwara and Kaduna States Nigeria, respectively.

\section{MATERIALS AND METHODS Sample Collection}

Honey samples used for this study were purchased from local harvesters from four different states in Nigeria; Warra in Kebbi State, Nasko in Niger State, Lafiagi in Kwara State and Dongu-Daji in Kaduna State, designated as samples $A, B, C$ and $D$, respectively. They were separately collected in sterilized airtight glass bottles and kept in dark cupboard and separately analyzed at The Center for Genetic Engineering and Biotechnology, Federal University of Technology Minna, Niger State, Nigeria.

\section{Determination of Phytate}

Phytate was determined according to the method described by Norhaizan and Nor Faizadatul Ain (2009). To $20 \mathrm{ml}$ of distilled water, $4.0 \mathrm{~g}$ of sample A was added, stirred and filtered. Then, 5 $\mathrm{ml}$ of the filtrate was taken into the conical flask and $4.0 \mathrm{ml}$ of reagents containing $2.0 \mathrm{ml}$ of $0.03 \%$ $\mathrm{FeCl}_{3}$ solution and $2.0 \mathrm{ml}$ of $0.3 \%$ sulphosalicyclic acid was added until a brownish yellow color persisted for 5 minutes. The absorbance of the supernatant was measured at $500 \mathrm{~nm}$ using a spectrophotometer (Bulk Scientific AAS; Model: Accusys 211: USA). A calibration curve for the colorimetric method was obtained by using sodium phytate standards. The same procedure was used for samples $B, C$ and
D. Three replicates were determined for each sample.

\section{Determination of Oxalate}

The method described by Day and Underwood (1986) was used in the determination of oxalate in of each of the sample. To $10 \mathrm{ml}$ of distilled water, $2.5 \mathrm{~g}$ sample A was added in a corked conical flask. Oxalate in solution was precipitated with $\mathrm{CaCl}_{3}$ as calcium oxalate. The precipitate was then washed with $20 \mathrm{ml}$ of $25 \% \mathrm{H}_{2} \mathrm{SO}_{4}$ and dissolved in hot water, then titrated with $0.05 \mathrm{~N}$ $\mathrm{KMnO}_{4}$ to determine the concentration of oxalate until a pink colour was observed $(1 \mathrm{ml}$ of $0.05 \mathrm{~N}=$ $0.045 \mathrm{~g}$ oxalic acid). The concentration of oxalate was determined using expression (1).

concentration of oxlalate $=\frac{T V \times E Q V \times W T \times D F \times 3.55}{W} \times 100$

Where TV = Titre Value; Eqv. Wt $=$ Equivalent Weight; D.F = Dilution Factor; $3.55=$ PhytinPhorsphorus Factor; $100=$ Conversion Factor to $\mathrm{mg} / 100 \mathrm{~g}$ of sample and $\mathrm{W}=$ Weight of Sample. Three replicates were determined for each sample.

\section{Determination of Tannin}

Tannin was determined according to Van-Burden and Robinson (1981) method. To $100 \mathrm{ml}$ of distilled water $5 \mathrm{~g}$ of sample was added in a $250 \mathrm{ml}$ beaker. This was shaken for $1 \mathrm{~h}$ in a mechanical shaker. This was filtered into $100 \mathrm{ml}$ volumetric flask and made up to the mark. Then, $1 \mathrm{ml}$ of the filtrate was pipetted into test-tube and mixed with $0.4 \mathrm{ml}$ of $0.1 \mathrm{M} \mathrm{FeCl}_{2}$ in $0.1 \mathrm{~N} \mathrm{HCl}$ and $0.008 \mathrm{M}$ potassium ferrocyanide. After 10 minutes, the absorbance was measured at 550 $\mathrm{nm}$ and the tannin concentration determined according to expression (2)

Concentration of tannin $(\mathrm{mg} / 100 \mathrm{~g}) \mathrm{C}_{\mathrm{U}}=\frac{\mathrm{Au}}{\mathrm{As}} \times \mathrm{CS} \times 1000$

$\mathrm{AU}=$ absorbance of unknown sample, $\mathrm{AS}=$ absorbance of standard, $\mathrm{CS}=$ concentration of standard, $\mathrm{CU}=$ concentration of unknown sample 
and $1000=$ conversion factor to $\mathrm{mg} / 100 \mathrm{~g}$. Three replicates were determined for each sample.

\section{Determination of Cyanide}

Cyanide was determined by a modified procedure of method described by Orjiekwe et al. (2013). To $50 \mathrm{ml}$ of distilled water, $10 \mathrm{~g}$ of sample was added in a corked conical flask. The mixture was subsequently filtered to obtain soluble cyano-glucosides as filtrate. The filtrate was mixed with Picric acid. In the presence of free cyanide, picric acid is reduced to the coloured isopurpuric acid, with the colour intensity directly proportional to the concentration of free cyanide originally present in the sample. Thereafter, the absorbance of the solution was measured using a spectrophotometer at wavelength of $510 \mathrm{~nm}$. A standard calibration curve of absorbance against cyanide concentration in $\mathrm{HCN}$ equivalent was plotted. Three replicates were determined for each sample.

\section{Determination of Saponin}

Total saponin in the samples was determined as described by Arivalagan et al. (2013) with some modifications. Sample A (1g) was mixed with 9 $\mathrm{ml}$ of water in a corked conical flask and thoroughly stirred. Then, $5 \mathrm{ml}$ of the solution was dissolved in $2 \mathrm{ml}$ of ethyl acetate, to which $1 \mathrm{ml}$ of $0.5 \%(\mathrm{v} / \mathrm{v}) p$-anisaldehyde in ethyl acetate and $1 \mathrm{ml}$ of $50 \%(\mathrm{v} / \mathrm{v}) \mathrm{H}_{2} \mathrm{SO}_{4}$ in ethyl acetate was added. Reaction mixtures were then incubated at $60^{\circ} \mathrm{C}$ for 10 minutes for colour development. Saponin present in samples is deglycosylated via acid hydrolysis, such that chromophore development arises from total saponin + sapogenin in a sample. After 10 min incubation, each tube was placed in a cold tap water bath. An aliquot of $0.5 \mathrm{ml}$ of distilled water was added to each tube. The absorbance of the colour developed solution was measured in a spectrophotometer at $430 \mathrm{~nm}$. Diosgenin in $2 \mathrm{ml}$ ethyl acetate was used as standard. The same procedure was used for samples $B, C$ and $D$. Three replicates were determined for each sample.

\section{Statistical Analysis}

Triplicate data of the samples were expressed as mean \pm standard deviation and were subjected to one-way analysis of variance (ANOVA) for the concentrations of cyanide, phytate and tannin. Then means were separated by Fisher's Least Significance Difference (LSD) at $p<0.05$. While students' t-test was used to compare the concentrations of oxalate and saponin.

\section{RESULTS}

\section{Anti-nutrient contents}

The result of anti-nutrient contents is shown in Table 1. Sample D has higher $(p>0.05)$ cyanide values $(59.17 \pm 0.19 \mathrm{mg} / 100 \mathrm{~g})$ when compared to samples A, B and C. Oxalate was only detected in samples $C$ and $D$. The result also indicated that sample A showed the highest phytate concentration $(961.20 \pm 28.71 \mathrm{mg} / 100)$ and this was significantly different $(p<0.05)$ when compared with samples $B, C$ and $D$. The concentration of Tannin (426.14 \pm 11.43 $\mathrm{mg} / 100 \mathrm{~g}$ ) in sample $B$ was significantly higher $(p<0.05)$ as compared to that of samples $A, C$ and $D$. Saponin was detected in samples $C$ $(14.47 \pm 0.11 \mathrm{mg} / 100 \mathrm{~g})$ and $D(15.63 \pm 0.10$ $\mathrm{mg} / 100 \mathrm{~g}$ ) only and the concentrations were significantly different $(p<0.05)$.

\section{DISCUSSION}

Anti-nutrients were detected in the honey samples under investigation. These substances are secreted by plants as anti-feedants against insect herbivores. The anti-nutrient constituents of the four honey samples showed that cyanide concentrations ranged between 29.71 and 59.17 $\mathrm{mg} / 100 \mathrm{~g}$. Cyanide in the honey samples was higher than $0.005 \mathrm{mg} / 100 \mathrm{~g}$ reported for honey collected from Biase Southern Senetorial District of Cross River State, Nigeria by lgbang et al. (2018) and 18.99-19.13 mg/100g of honey collected from Akure, Ondo State, Nigeria (Adeniyi et al., 2016). 
Nigerian Journal of Basic and Applied Science (December, 2019), 27(2): 32-38

Table 1: Anti-nutrient composition honey from four Northern States of Nigeria $(\mathrm{mg} / 100 \mathrm{~g})$

\begin{tabular}{lccccc}
\hline $\begin{array}{l}\text { Sample } \\
\text { (mg/100g) }\end{array}$ & Cyanide & Oxalate & Phytate & Tannin & Saponnin \\
\hline A & $29.71 \pm 0.01^{\mathrm{a}}$ & $\mathrm{ND}$ & $961.20 \pm 28.71^{\mathrm{a}}$ & $390.32 \pm 3.83^{\mathrm{a}}$ & $\mathrm{ND}$ \\
$\mathrm{B}$ & $29.71 \pm 0.01^{\mathrm{a}}$ & $\mathrm{ND}$ & $754.24 \pm 29.46^{\mathrm{b}}$ & $426.14 \pm 11.43^{\mathrm{b}}$ & $\mathrm{ND}$ \\
$\mathrm{C}$ & $34.83 \pm 0.08^{\mathrm{b}}$ & $3.70 \pm 0.02^{\mathrm{a}}$ & $22.29 \pm 0.03^{\mathrm{c}}$ & $329.49 \pm 19.75^{\mathrm{c}}$ & $14.47 \pm 0.11^{\mathrm{a}}$ \\
D & $59.17 \pm 0.19^{\mathrm{c}}$ & $4.72 \pm 0.01^{\mathrm{b}}$ & $79.21 \pm 1.09^{\mathrm{d}}$ & $278.48 \pm 0.27^{\mathrm{d}}$ & $15.63 \pm 0.10^{\mathrm{b}}$ \\
LSD $_{0.05}$ & 0.52 & & 43.12 & 24.62 & \\
\hline
\end{tabular}

$\mathrm{ND}$, not detected

The values given are means of triplicate analysis. Mean values in the same column with the same superscript letters are not significantly different

The maximum recommended acute reference doses (ARfD) for cyanide from consumption of foods with cyanogenic glycosides in humans are $4.5 \mathrm{mg} / 60 \mathrm{~kg}$ body mass (Abraham et al, 2016) and $5.4 \mathrm{mg} / 60 \mathrm{~kg}$ body mass (JECFA, 2012). Thus, excessive consumption of this honey in a single dose could result in cyanide toxicity. Higher cyanide ions in human have been reported to inhibit cytochrome oxidase, ATP formation and energy generation as well as death (Akyildiz et al., 2010). Chronic exposure to high cyanide could also result in deficiency in amino acid cysteine, vitamin $\mathrm{B}_{12}$ and iodine in human (WHO, 2004).

Oxalate had the lowest quantity (3.70-4.72 $\mathrm{mg} / 100 \mathrm{~g}$ ) among the anti-nutrients detected in the honey samples. It occurs only in honey samples from Kwara and Kaduna States. This is similar to the finding of Igbang et al. (2018) who did not detect oxalate in the honey sample from Biase Southern Senetorial District of Cross River State, Nigeria. The value of oxalate reported in this study is lower compared to values obtained for sweet and bitter honey (59.40-59.50 $\mathrm{mg} / 100 \mathrm{~g}$ ) from Akure, Ondo State, Nigeria (Adeniyi et al., 2016). Oxalate content in the sampled honey in this study is lower than the average of $200 \mathrm{mg} / \mathrm{kg}$ recommended for honey (EMEA, 2003). It also fell below the range of 5$500 \mathrm{mg} /$ daily consumption reported for Europeans diets (EMEA, 2003). Higher consumption of oxalate in diet could result in oxalic acid forming insoluble salts with divalent ions like $\mathrm{Ca}^{2+}, \mathrm{Fe}^{2+}$ and $\mathrm{Mg}^{2+}$ thereby rendering them unavailable for absorption in human system (Groff et al.,1995). Consumption of moderate oxalate in food, however, enhances immune response to diseases and prevention of cancerous cells growth (Hodgkinson, 1977).

Tannin concentrations (278.48-426.14 mg/100g) in all the samples were higher than the tannin levels $(0.59 \mathrm{mg} / 100 \mathrm{~g})$ reported for samples obtained from other regions of the country (lgbang et al., 2018), but lower than the average consumption of $1000 \mathrm{mg} / \mathrm{day}$ and $820 \mathrm{mg} / 100 \mathrm{~g}$ as obtained in the USA and Spain, respectively (Chun et al., 2007; Tresserra-Rimbau et al., 2013). Tannin has a number of nutritional and health benefits such as being an anti-oxidant, cardio-protective, anti-inflammatory, anticarcinogenic and anti-mutagenic (Kumari and Jain, 2012). Similarly, plants containing tannin have been reported to be used for healing of wounds, varicose ulcers, hemorrhoids, frost bile and burn in herbal medicine. However at higher concentrations, tannins may complex with food thereby rendering digestive enzymes like trypsin, chemotrypsin, amylase and lipase less effective (Felix and Mello, 2000).

Phytate is the most abundant of the anti-nutrients $(22.29-961.20 \mathrm{mg} / 100 \mathrm{~g})$ tested for in this study. Phytate constituent in this study is higher than $0.38 \mathrm{mg} / 100 \mathrm{~g}$ reported for honey sample from Biase Southern Senetorial District of Cross River State, Nigeria (lgbang et al.,, 2018) and 1.98$2.01 \mathrm{mg} / 100 \mathrm{~g}$ reported for samples from Akure, 
Ondo State, Nigeria (Adeniyi et al., 2016). This is also less than the average daily consumption of 2000-2600 mg and 150-1400 mg for vegetarians and humans with mixed diets, respectively (Reddy, 2002). Phytate in human diets significantly lowers cholesterol and the risk of coronary diseases (Klevay, 1974; Jeriwalla et al., 1990). It also helps in the management and prevention of diabetes as well as growth of different cancer line (Yoon et al., 1983; Thompson, 1993; Shamsuddin et al., 1996). However, at higher consumption rate, phytate has been associated with nutritional diseases such as ricket in children and osteomalacia in adults (Adeniyi et al., 2016).

Saponin content (14.47-15.63 mg/100g ) was observed to be high when compared to $1.43-2.44$ $\mathrm{mg} / 100 \mathrm{~g}$ saponin content of honey from Pakistan (Khaliqur et al., 2013) and $3.05-3.15 \mathrm{mg} / 100 \mathrm{~g}$ reported for sweet and bitter honeys from Akure, Ondo State, Nigeria (Adeniyi et al., 2016). Saponin rich diets are important in the control of plasma cholesterol, prevention of peptic ulcer, osteoporosis and reduction in the risks of heart diseases (Gemede and Retta, 2014). However, higher concentration of saponin in human diet could reduce bioavailability of nutrients, enzyme activity and protein digestibility (Liener, 2003).

The anti-nutritional compositions of honey samples differ greatly according to their floral sources, honey bee species, geographical area, season, mode of storage and technology (Cantarelli et al., 2008; Ebenezer and Olubenga, 2010). These factors may have influenced the differences observed in the amount and types of phytoconstituents detected in the honey samples (Adeniyi et al., 2016; Igbang et al., 2018).

\section{CONCLUSION}

The study revealed significant differences in the concentrations of various anti-nutrients in the sampled honeys probably influenced by differences in their botanical and geographical origins. With the exception of cyanide that was detected in samples $C$ and $D$, all other antinutrients were within the acceptable limits for human consumption. Therefore, it is recommended that when choosing honey for human consumption, the levels of the antinutrients contents should be considered.

\section{REFERENCES}

Abraham, K., Buhrke T. and Lampen A. (2016). Bioavailability of cyanide after consumption of a singlemeal of foods containing high levels of cyanogenic glycosides: a crossover study in humans. Archives of Toxicology, 90: 559-574.

Adeniyi, K .A., Olayemi, I. K., Shittu K. O., Busari M. B., Mohammed Sanni S. Bashir L., Yusuf, R. S. (2016). Comparative phytochemical and antinutritional constituents of Nigeria sweet and bitter honey varieties. World Journal of Pharmaceutical Research, 5(3):255-267.

Akande, K. E., Doma, U. D., Agu, H. O. and Adamu, H. N. (2010). Major Antinutrients Found in Plant Protein Sources: Their Effect on Nutrition. Pakistan Journal of Nutrition, 9(8): 827-832

Akiyama, H., Fujii, K., Yamasaki, O., Oono, T. and Iwatsuki, K. (2001). Antibacterial action of severaltannins against Staphylococcus aureus. Journal of Antimicrobial Chemotherapy, 48(4): 487491.

Akyildiz, B.N., Kurtoglu, S., Kondolot, M. and Tunc, A. (2010). Cyanide Poisoning caused by Ingestion of Apricot seeds. Annals of Tropical Paediatric, 30(1): 3943.

Arivalagan, M., Gangopadhyay K. K. and Kumar, G. (2013). Determination of Steroidal Saponins and Fixed Oil Content in Fenugreek (Trigonella FoenumGraecum) Genotypes. Indian Journal of Pharmaceutical Sciences. 75(1): 110113.

Brian, P. D. (2015). Toxic honey. http://www.dave-cushman.net/ accessed on 21/11/16.

Buba, F., Gidado, A. and Shugaa, A. (2013). Analysis of Biochemical Composition of 


\section{Nigerian Journal of Basic and Applied Science (December, 2019), 27(2): 32-38}

Honey Samples from North-East Nigeria. Biochemistry and Analytical Biochemistry, 2(3):1-7.

Cantarelli, M. A., Pellerano, R. G., Marchevsky, E. J., Camina, J. M. (2008) Quality of honey from Argentina: study of chemical composition and trace elements. The Journal of the Argentine Chemical Society, 96: 33-41.

Chun, O. K., Chung, S. J., Song W. O. (2007). Estimated dietary flavonoid intake and major food sources of U.S. adults. Journal of Nutrition, 137:1244-52

Codex Alimentarius Commission (CAC) (2001). Codex standard for honey FAD, Rome. Alinorm 1:19-26.

David, W. B., (2007). The Chemical Composition of Honey". Journal of Chemical Education, 84(10): 1643-1646.

Day, R. A. and Underwood A. L. (1986). Quantitative analysis (5thed.). Prentice, Hall publication, pp701.

Ebenezer, I. O. and Olubenga, M. T. (2010). Pollen characterization of honey samples from North Central Nigeria. Journal of Biological Sciences, 10: 43-47.

European Medicines Agency (EMEA) (EMEA) (2003). Committee for Veterinary Medicinal Products (Oxalic Acid). Summary Report. EMEA/MRL/891/03FINAL. www.emea.eu.int. Accessed 05/07/19.

Felix, J. P. and Mello, D. (2000). Farm Animal Metabolism and Nutrition. United Kingdom: $\mathrm{CABI}$ Publishing Wallingford, UK. pp450.

Gemede, H. F. and Retta, N. (2014). Nutritional factors in Plants foods: Potential Health benefits and adverse effects. International Journal of Food Sciences and Nutrition, 3(4): 284-289.

Gilani, G. S., Xiao, C. W. and Cockell, K. A. (2012) Impact of antinutritional factors in food proteins on the digestibility of protein and the bioavailability of amino acids and on protein quality. British Journal of Nutrition, 108: 315-332.

Groff, J., Gropper, S. and Hunt, S. (1995). Advanced Nutritional and Human Metabolism. 2nd Ed., New York. Pp221362.

Hodgkinson, A. (1977). Oxalic acid in biology and medicine. Academic Press London. pp325

lgbang, O. J., Abang, O, Eneji, E. G. (2018). Selected Antinutrients and Proximate Compositions of Honey (Apismellifera) Sample Collected from Biase, Southern Senatorial District of Cross River State, Nigeria. Biochemical Pharmacolology (Los Angel), 7 (4): 261.

JECFA, Joint FAO/WHO Expert Committee on Food Additives (2012). Cyanogenic glycosides. In: WHO food additives series no. 65 , safety evaluation of certain food additives and contaminants. WHO, Rome, pp 171-323. ISBN: 978-92-4166065-5.

http://whqlibdoc. who.int/publications/2012/97892 41660655_eng.pdf.(Accessed 08 Feb 2015)

Jariwalla, R. J, Sabin, R., Lawson, S. and Herman, Z. S. (1990). Lowering of serum cholesterol and triglycerides and modulation of divalent cations by dietary phytate. Journal of Applied Nutrition; 42: 18-28.

Kaskoniene, V., and Venskutonis, P. R. (2010). Floral markers in honey of various botanical and geographic origins: A review. Comprehensive Reviews in Food Science and Food Safety, 9: 620-634.

Khaliqur, R., Arshad, A., Shafqat, U. and Indad, U. M. Z. (2013). Phytochemical analysis and chemical composition of different branded and umbranded honey sample. International Journal of Microbiological Research, 4(2): 132-137.

Klevay, L. M. (1974). Coronary heart disease: The Zinc/Copper hypothesis. American Journal Clinical Nutrition, 28:764-774. 
Kumari, M. and Jain, S. (2012). Tannins: An Antinutrient with Positive Effects to Manage Diabetes. Research Journal of Recent Sciences, 1(12): 70-73

Liener, I. E. (2003). Phytohaemagglutannin: Their nutritional significance. Journal of Agriculture Food Chemistry, 22:71

Norhaizan, M. E. and Nor Faizadatul Ain, A. W. (2009). Determination of Phytate, Iron, Zinc, Calcium Contents and Their Molar Ratios in Commonly Consumed Raw and Prepared Food in Malaysia. Malaysia. Journal of Nutrition; 15(2):213-222

Okaka, J.C. and Okaka, A.N.C. (2005) Foods: Composition, Spoilage, Shelf life Extension. OCJANCO Academic Publishers, Independent Layout, Enugu. Nigeria. Pp57-58

Orjiekwe, C. L., Solola, A., Iyen, E. and Imade, S. (2013). Determination of cyanogenic glucosides in cassava products sold in Okada, Edo State, Nigeria. African Journal of food Science, 7(12):468-472

Oyeleke, S. B., Dauda, B.E.N., Jimoh, T. and Musa, S.O. (2010). Nutritional Analysis and Antibacterial Effect of Honey on Bacterial Wound Pathogens. Journal of Applied Sciences Research, 6(11): 15611565

Reddy, N. R. (2002). Occurrence, distribution, content, and dietary intake of phytate. In N. R. Reddy and S. K. Sathe (Eds.), Food phytates. Boca Raton, Florida: CRC Press. Pp.25-51.

Shamsuddin, A. M., Yang, G. Y. and Vucenik, I. (1996). Novel anti-cancer functions of IP6: Growth inhibition and differentiation of human mammary cancer cell lines in vitro. Anticancer Research, 16:3287-3292.

Shanthakumari, S., Mohan, V. and Britto, J. (2008). Nutritional evaluation and elimination of toxic principles in wild yam (Dioscorea spp.). Tropical and Subtropical Agroecosystems, 8:319 - 225.

Špánik, I. Pažitná A., Šiška P. and Szolcsányi P. (2014). The determination of botanical origin of honeys based on enantiomer distribution of chiral volatile organic compounds. Food Chemistry. 158: 497503

Thompson, L. U. (1993). Potential health benefits and problems associated with antinutrients in foods. Food Research International, 26(2): 131-149.

Tresserra-Rimbau, A., Medina-Remón, A., PérezJiménez, J., Martinez-Gonzalez M. A., Covas M. I., Corella D., Salas-Salvado J., Gomez-Gracia E., Lapetra J., Aros F., Fiol M. and Rose E. (2013). polyphenols in a Spanish population at high cardiovascular risk: the PREDIMED study. Nutritional Metabolism Cardiovascular Diseases, 23:953-959.

Van-Burden, T. P. and Robinson, W. C. (1981). "Formation of Complexes between Protein and Tannin Acid", Journal of Agriculture and Food Chemistry, 1: 77.

World Health Organization (2004). Hydrogen cyanide and cyanides: Human health aspects. Concise International Chemical Assessment Document 61. www.who.int/pc/ra/cicads.htm. Accessed 27/2/2015.

WHO (2006). Joint FAO/WHO Expert Committee on Food Addictives. Quillaia Extract. WHO Technical Report Series N0934, pp 28-33.

Yoon, J. H., Thompson, L. U., and Jenkins, D. J. A. (1983). The effect of phytic acid on in vitro rate of starch digestibility and blood glucose response. American Journal of Clinical Nutrition, 38: 835-842. 